\title{
ДОКЛІНІЧНІ ДОСЛІДЖЕННЯ ДЕЗІНФІКУЮЧИХ ВЛАСТИВОСТЕЙ ПРЕПАРАТУ „КОНТАВІР»
}

\author{
Неджеря Тетяна Іванівна \\ аспірант кафедри акушерства та хірургії \\ Сумський національний аграрний університет (м. Суми, Україна) \\ ORCID: 0000-0002-4972-7935 \\ tatyananedzheria@ukr.net
}

Однією з невирішених проблем для санітарії та гігієни у ветеринарній медицині є виникнення резистентності у мікроорганізмів до певних груп дезінфректантів, які постійно використовуються. Тому виникає необхідність створення нових комплексних дезінфрікуючих засобів. Метою роботи було проведення доклінічних досліджень дезінфрікуючих властивостей засобу «Контавір». Дослідження проводили в умовах навчально-наукової лабораторії «Ветеринарна фрармація» Сумського національного аграрного університету.

Проводили визначення бактерицидного розведення та фенольного коефріцієнта дезінфектанту «Контавір». Експеримент починали з приготування розчину дезінфектанту «Контавір» та культур мікроорганізмів $E$. coli ma $S$. aureus. Встановлено, що бактерицидна дія засобу «Контавір» сильніша за бактерицидну дію карболової кислоти в 131,5 рази. B присутності високомолекулярного білка бактерицидна дія засобу «Контавір» знижується в 1,61 рази.

Визначали ефрективність дії дезінфектанту «Контавір» на тест-об'єктах: бетон, пластик, кахель та метал. Визначення якості проведеної дезінфекції проводили через 10, 40 та 60 хвилин. Доведено, що дезінфектант «Контавір» проявляє бактерицидні властивості через 10 хвилин експозиції у концентрації 0,25 \% на поверхні металу, пластику та кахелю. На неоднорідній поверхні бетону дезінфектант знищує колонії E. coli через 60 хвилин експозиції.

Також проводили дослідження бактерицидної активності дезінфрікуючого засобу «Контавір» суспензійним методом що до ентеробактерій, грампозитивних коків, грамнегативних паличок та бацил суспензійним методом. Засіб дезінфрікуючий «Контавір» у концентрації 0,1% проявляє бактерицидну активність стосовно S. aureus 209-P, Salmonela Cholerasuis, Streptococcus faecium, Clostridium perfringens, Klebsiella spp., nри експозиції 60 хвилин, а із Enretobacter spp. npu 30 хвилинах контактування. Антимікробні властивості дезінфектант проявляє в концентрації 0,25 та 0,5 \% стосовно S. aureus 209-P, Salmonela Cholerasuis, Streptococcus faecium, Clostridium perfringens, Klebsiella spp., Enretobacter spp. npu ексозиції 30 хвилин.

Дослідження віруліцидної дії засобу «Контавір» суспензійним методом проводили відносно ДНК- та РНК-містких вірусів. Встановлено, що «Контавір» у концентрації 0,25 \% при експозиції 30 хвилин проявляє віруліцидну дію стосовно збуднику трансмісивного гастроентериту свиней; при експозиції 60 хвилин - до збудників хвороби Ауєскі; парагрипу-3 великої рогатої худоби та вірусної діареї великої рогатої худоби. Дезінфрікуючий засіб «Контавір» у концентрації 0,25 \% при експозиції 60 хвилин проявляє віруліцидну дію стосовно збуднику хвороби Тешена; при екпозиції 30 хвилин в концентрації 0,5 \% відносно хвороби Ньюкасла; хвороби Гамборо та хвороби Марека.

Ключові слова: фенольний коефріцієнт, білковий індекс, бактерицидна активність, тест-об'єкти, віруліцидна активність.

DOI: https://doi.org/10.32845/bsnau.vet.2020.4.5

Вступ. Існує безліч засобів для чищення та дезінфікуючих засобів, доступних для використання в тваринницьких приміщеннях. Вибір ефрективного дезінфектанту для використання на вашій фермі вимагає ретельного вивчення історії недавніх захворювань і ряду інших специфічних факторів ферми, включаючи жорсткість і рН води, типи підлог i інших поверхонь, потенційні проблеми для навколишнього середовища, досвід персоналу і вартість.

Дезінфекція у приміщеннях для утримання тварин відіграє важливу роль для недопущення виникнення та розповсюдження інфекції. Кожен дезінфікуючий засіб має певні хімічні властивості. Важливо визначитись з необхідною ефективною концентрацію робочого розчину засобу при проведенні дезінфекції. Створення кожного дезінфектанту починають в лабораторних умовах. Засіб, який виявився ефективним y in vitro, може бути рекомендований для подальшого дослідження у виробничих умовах.

Аналіз основних досліджень і публікацій. Довгі дебати ведуться навколо питання про те, чи корисно чергувати дезінфікуючі засоби, що використовуються в тваринництві, щоб запобігти селекцію стійких штамів патогенних організмів. Ротація дезінфікуючих засобів часто застосову-

ється в лікарнях і на підприємствах з виробництва ліків (Tenzin et al., 2019) проте в системах тваринництва це практикується рідше.

За минулі роки ветеринарні лікарі стикнулися з безліччю інформації про те, які дезінфікуючі засоби використовувати на взуття, черевиках, шинах або іншому обладнанні, щоб вбити вірус ящуру або грипу. Перш ніж вибирати дезінфікуючий засіб для повсякденного використання на фермі, слід врахувати кілька важливих моментів щодо дезінфекції. По-перше, більшість дезінфікуючих засобів не подіють, якщо дезінфіціруемая поверхня не чиста (через наявність органічних речовин, таких як бруд або гній) перед нанесенням дезінфікуючого засобу (Fablet et al., 2012).

Парові апарати і апарати високого тиску можуть бути дуже корисні для очищення пористих поверхонь. Органічні матеріали, такі як ґрунт, рослинні залишки (наприклад, солома), молоко, кров, гній і гній, часто інактивують деякі дезінфікуючі засоби або захищають мікроби від активних інгредієнтів дезінфікуючого засобу. Цій проблемі особливо схильні до дезінфікуючі засоби на основі хлору. Хлор, активний інгредієнт відбілювача, відносно швидко інактивується органічними залишками, такими як гній і навіть молоко, в концен- 
траціях, зазвичай використовуваних на чистих поверхнях (Chang et al., 2013).

Крім того, навіть «жорстка» вода може знизити або знищити дію деяких дезінфікуючих засобів. Точно так же деякі дезінфікуючі розчини активні тільки протягом декількох днів після змішування або приготування. Нездатність приготувати свіжий розчин дезінфікуючого засобу після того, як він був приготовлений довше, ніж кілька днів, або після того, як він став помітно забруднений органічними речовинами, такими як гній, може привести до використання продукту, який дійсно не працює. Гірше того, це може дати помилкове відчуття безпеки. Вірно, що достатня концентрація і час контакту можуть подолати деякі з цих проблем з певними класами дезінфікуючих засобів, але часто збільшення концентрації або часу контакту робить використання продукту непрактичним, дорогим або їдким (Shkromada \& Nedzheria, 2020).

Дезінфікуючі засоби також значно різняться за своєю активністю проти різних мікробів - бактерій, вірусів, грибів і найпростіших. Наприклад, простий оцет (4-відсоткова оцтова кислота) легко вбиває вірус ящура, але не має значного впливу на Mycobacterium paratuberculosis. Найбільш часто вживані дезінфрікуючі засоби не активні проти бактеріальних спор, екологічно стійкої форми життя, яку приймають мікроби, що викликають правець, ботулізм і сибірку (Ogunniyi et al., 2019). Так, формальдегід ефективний проти більшості мікроорганізмів, але насправді він не є практичним дезінфікуючим засобом і тепер вважається потенційно небезпечною сполукою, що викликає онкологічні захворювання у людей.

Важливо вибрати дезінфікуючий засіб, яке буде діяти щодо широкого спектра мікробів в умовах, в яких він зазвичай використовується. Ці умови включають жорстку воду, забруднення органічними речовинами і потенційну токсичність або пошкодження огороджувальних конструкцій, шкіри та одягу (Díaz et al.,2018). Також важливо, щоб розчини були чистими і тільки що виготовленими відповідно до вказівок виробника.

Нарешті, дезінффікуючі засоби повинні мати достатній час контакту 3 поверхнями, на які вони наносяться, щоб дозволити їм знищіти мікроорганізми.

Більш старі засоби на основі сполук четвертинного амонію (Roccal D тм) підходять для деяких ситуацій і відносно чистих поверхонь та дезінфекції. Нажаль вони не будуть особливо ефективні проти ящуру або М. paratuberculosis, i мають помітно знижену активність в присутності органічних речовин. Деякі з нових засобів четвертинного амонію мають підвищену активність, проте вони зазвичай швидко інактивуються при контакті з милом або залишками мила (Chen et al.,2015).

Сполуки на основі френолу є похідними кам'яновугільної смоли і часто мають сильний запах соснової смоли. Зазвичай вони стають молочними при додаванні в воду і мають гарну активністю в жорсткій воді і в присутності деяких органічних речовин. Вони вважаються активними проти багатьох бактерій, вірусів і грибів, включаючи бактерії, що викликають туберкульоз. Вони не особливо активні проти вірусів, проте вони є гарним універсальними дезінфікуючими засобами для використання на фрермах (Shkromada et al.,2019). Деякі приклади дезінфікуючих засобів цього класу включають One Stroke Environ $\circledast$, Osyl® i Amphyl®.
Сполуки хлору є хорошими дезінфікуючими засобами для чистих поверхонь і мають широкий спектр дії. Зазвичай вони більш активні в теплій воді. Вони можуть викликати корозію металів і шкодити одяг, гумові вироби. Їх активність сильно знижується через наявність органічних речовин. Багато хлорних сполук нестабільні і вимагають частої заміни (Dennler-Church et al., 2020).

Регулярно вводяться нові дезінфікуючі засоби (Wohlgemuth et al., 2020). Для підвищення ефективності дезінфектанту створюються нові багатокомпонентні засоби. За використання декількох сполук, які синергетично пов'язані між собою, не виникає проблема із виникненням резистентності у мікроорганізмів до певних хімічних комплексів. Також збільшується спектр протимікробної дії у комплексного дезінфрікуючого засобу.

Мета. Метою роботи було проведення доклінічних досліджень дезінффікуючих властивостей засобу «Контавір».

Матеріали і методи. Дослідження проводили в умовах навчально-наукової лабораторії «Ветеринарна фармація» та на кафедрі ветсанекспертизи, мікробіології, зоогігієни та безпеки і якості продуктів тваринництва Сумського національного аграрного університету. визначення бактерицидного розведення та фенольного коефіцієнта дезінфектанту «Контавір». Експеримент починали з приготування розчину дезінфектанту «Контавір» та культур мікроорганізмів E. coli та S. aureus. До кожного розведення дезінфектанту «Контавір» додавали 0,2 см³ двохмільярдної суспензії добової культури мікроорганізмів. Також через 30 хв., отримували проби і виконували повторний посів на МПБ. Пробірки 3 МПБ витримували в термостаті при температурі $37^{\circ} \mathrm{C}$ протягом 24 годин.

Визначали ефективність дії дезінфектанту «Контавір» на тест-об'єктах: бетон, пластик, кахель та метал. Визначення якості проведеної дезінфекції проводили через 10, 40 та 60 хвилин.

Проводили визначення віруліцидної активності дезінфектанту «Контавір» відносно ДНК- містких вірусів: хвороба Ауєскі; Трансмісивний гастроентерит; парагрип великої рогатої худоби; вірусна діарея великої рогатої худоби та РНК- містких вірусів: збудник хвороби Ньюкасла; Гамборо; Марека; хвороба Тешена.

Також проводили дослідження бактерицидної активності дезінфікуючого засобу «Контавір» суспензійним методом що до ентеробактерій, грампозитивних коків, грамнегативних паличок та бацил суспензійним методом. Для визначення бактерицидної дії дезінфектанту «Контавір» використовували штами S. aureus 209-P, Salmonela Cholerasuis, Streptococcus faecium, Clostridium perfringens, Klebsiella spp., Enretobacter spp., у концентрації 2 млрд./см 3 та розчин «Контавір» 0,1; 0,25; 0,5 \% при експозиції 30 та 60 хвилин. Також проводили розведення дезінфектанту «Контавір» у відповідних концентраціях. Тест культури вносили у пробірки 3 дезінфектантом. Контроль росту мікроорганізмів здійснювали візуально та шляхом мікроскопії мазків. Наявність чи відсутність росту обраних для експерименту мікроорганізмів дає уявлення про активність дезінфектанту. У випадку появи росту мікроорганізмів, слід збільшити концентрацію, температуру і витрати дезінфректанту «Контавір» на 1 см 2 і провести повторну серію аналогічних досліджень (Golovko \& Ushkalov , 2004; Methodical recommendations, 2007).

\section{Результати досліджень.}


Розробку рецептури препарату «Контавір» ми проводили, виходячи з фізико-хімічних властивостей його складників. При цьому звертали увагу на розчинність усіх компонентів у воді при різних температурах, на наявність осаду чи пластівців на поверхні розчину, наявність мутності, стороннього запаху; перевіряли відсутність хімічної взаємодії між діючими речовинами препарату при їх змішуванні.

Підбираючи складники для майбутнього дезінфектанту, ставили за мету досягти широкого спектру його дії, а також поєднання в одному препараті дезінфекційних та дезінвазійних властивостей. Намагалися створити препарат якомога менш токсичний для людей і тварин, порівняно дешевий, простий у використанні, без неприємного запаху, з відповідними мийними властивостями.

В склад дезінфекційного засобу були включені такі хімічні речовини у наступному співвідношенні компонентів, мас. (г/кг): глутаровий альдегід - 50; бензалконій хлорид
-70; додецилдиметиламонію хлорид - 10; етоксильований спирт - 25; амінооксид ПАР генамінокс - 110.

Таким чином, було створено новий препарат - «Контавір», в якому поєднані дві речовини з різними хімічними властивостями та дією (дезінфекційна та дезінвазійна). Використання цього препарату дозволяє провести дезінфекцію та дезінвазію обробку одночасно. Обробку «Контавір» можна проводити також різними способами: промиванням, змочуванням, зануренням, протиранням, обприскуванням.

Визначення бактерицидного розведення та фенольного коефіцієнта дезінфектанту «Контавір». Експеримент починали з приготування розчину дезінфектанту «Контавір». Первинна концентрація розчину була 1:50 з поступовим зменшенням концентрації засобу при кожному розведенні. Крок розведення дорівнював 10. Також попередньо були проведені розведення культур мікроорганізмів E. coli та S. aureus. Результати досліджень наведені в таблиці 1.

Таблиця 1

Бактерицидне розведення «Контавір»

\begin{tabular}{|l|l|l|}
\hline \multirow{2}{*}{$\begin{array}{c}\text { Розчини засобу } \\
\text { «Контавір» }\end{array}$} & \multicolumn{2}{|c|}{ Бактерицидне розведення дезінфектанту } \\
\cline { 2 - 3 } & \multicolumn{1}{|c|}{ експозиція, хв. } \\
\cline { 2 - 4 } Фенол $1: 50$ & $1: 98$ & $1: 192,9$ \\
\hline «Контавір» $1: 50$ & $1: 12024,2$ & $1: 18128,0$ \\
\hline Білковий індекс & $1: 8016,0$ & $1: 10539,53$ \\
\hline
\end{tabular}

Фенольний коефіцієнт дає можливість порівнювати, наскільки бактерицидне розведення дезінфектанту відрізняється від бактерицидного розведення фенолу. Для отримання достовірних даних експеримент виконували у п'яти повторах вираховували середній показник бактерицидного розведення дезінфектанту та фенолу. Наступні розрахунки проводили таким чином. Бактерицидне розведення карболової кислоти при 10 хв. експозиції складає 1:98 та при 30 Хв. $-1: 192$.

В результаті проведеного дослідження встановлено, що бактерицидна дія засобу «Контавір» сильніша за бактерицидну дію карболової кислоти в 131,5 рази.

Визначення білкового індексу проводили для встановлення ефективності дезінфектанту «Контавір» у середовищі забрудненому органікою. Навіть після механічного очищення приміщення від гною, у холодильних камерах та молочній тарі залишаються рештки мертвих органічних клітин, з якими контактує дезінфектант і втрачає свою активність.

В результаті проведеного експерименту було встановлено, що бактерицидна дія засобу «Контавір» в присутності високомолекулярного білка знижується в 1,61 рази.

Визначення ефективності дії дезінфектанту «Контавір» на тест-об'єктах.

У наших дослідженнях для визначення ефективності дії дезінфектанту «Контавір» використовували бактерії $E$. coli при різних температурних режимах і способах кратності нанесення на тест-об'єкти до того часу, доки не була визначена мінімальна бактерицидна концентрація й експозиція деззасобу для зазначених мікроорганізмів. Результати досліджень наведені в таблиці 2.

Ефективність знезараження поверхні тест-об’єктів дезінфектантом «Контавір», контамінованих E. coli

\begin{tabular}{|c|c|c|c|c|}
\hline \multirow{2}{*}{ Тест-об'єкти } & \multirow{2}{*}{ Розчин дезінфектанту, \% } & \multicolumn{3}{|c|}{ Експозиція, хв } \\
\hline & & 10 & 40 & 60 \\
\hline \multirow{3}{*}{ Бетон } & 0,1 & + & + & + \\
\hline & 0,25 & + & + & - \\
\hline & 0,5 & - & - & - \\
\hline \multirow{3}{*}{ Пластик } & 0,1 & + & + & + \\
\hline & 0,25 & - & - & - \\
\hline & 0,5 & - & - & - \\
\hline \multirow{3}{*}{ Кахель } & 0,1 & + & + & + \\
\hline & 0,25 & - & - & - \\
\hline & 0,5 & - & - & - \\
\hline \multirow{3}{*}{ Метал } & 0,1 & + & + & + \\
\hline & 0,25 & - & - & - \\
\hline & 0,5 & - & - & - \\
\hline
\end{tabular}

Примітка: "+" - наявність росту, "-" - відсутність росту

За результатами проведених досліджень встановлено, що дезінфектант «Контавір» проявляє бактерицидні властивості через 10 хвилин експозиції у концентрації 0,25
\% на поверхні металу, пластику та кахелю. На неоднорідній поверхні бетону дезінфектант знищує колонії E. coli через 60 хвилин експозиції. Проведене дослідження вказує на те, що 
не різних матеріалах дезінфектант може проявляти бактерицидні властивості по-різному.

Також проводили дослідження бактерицидної активності дезінфікуючого засобу «Контавір» суспензійним методом що до ентеробактерій, грампозитивних коків, грамнегативних паличок та бацил суспензійним методом. Для визначення бактерицидної дії дезінфектанту « Контавір» викорис- товували штами S. aureus 209-P, Salmonela Cholerasuis, Streptococcus faecium, Clostridium perfringens, Klebsiella spp., Enretobacter spp., у концентрації 2 млрд./см³ та розчин «Контавір» 0,1; 0,25; 0,5 \% при експозиції 30 та 60 хвилин. Також проводили розведення дезінфектанту «Контавір» у відповідних концентраціях. Результати досліджень наведені в таблиці 3.

Оцінка бактерицидної активності дезінфрікуючого засобу «Контавір» суспензійним методом

Таблиця 3

\begin{tabular}{|c|c|c|c|c|c|}
\hline № & Культури мікроорганізмів & КУO в $1 \mathrm{~cm}^{3}$ & Тривалість експозиції, хв. & Концентрація дезінфектанту,\% & Результати досліджень \\
\hline \multirow{5}{*}{1} & \multirow{5}{*}{ S. aureus } & \multirow{5}{*}{$2 \times 10^{9}$} & 30 & \multirow{2}{*}{0,1} & + \\
\hline & & & 60 & & - \\
\hline & & & 30 & & - \\
\hline & & & 60 & 0,25 & - \\
\hline & & & 30 & 0,5 & - \\
\hline \multirow{5}{*}{2} & \multirow{5}{*}{ Salmonela Cholerasuis } & \multirow{5}{*}{$2 \times 10^{9}$} & 30 & \multirow{2}{*}{0,1} & + \\
\hline & & & 60 & & - \\
\hline & & & 30 & & - \\
\hline & & & 60 & 0,25 & - \\
\hline & & & 30 & 0,5 & - \\
\hline \multirow{5}{*}{3} & \multirow{5}{*}{ Streptococcus faecium } & \multirow{5}{*}{$2 \times 10^{9}$} & 30 & \multirow{2}{*}{0,1} & + \\
\hline & & & 60 & & - \\
\hline & & & 30 & & - \\
\hline & & & 60 & 0,25 & - \\
\hline & & & 30 & 0,5 & - \\
\hline \multirow{5}{*}{4} & \multirow{5}{*}{ Clostridium perfringens } & \multirow{5}{*}{$2 \times 10^{9}$} & 30 & \multirow{2}{*}{0,1} & + \\
\hline & & & 60 & & - \\
\hline & & & 30 & & - \\
\hline & & & 60 & 0,25 & \\
\hline & & & 30 & 0,5 & - \\
\hline \multirow{5}{*}{5} & \multirow{5}{*}{ Klebsiella spp } & \multirow{5}{*}{$2 \times 10^{9}$} & 30 & \multirow{2}{*}{0,1} & + \\
\hline & & & 60 & & - \\
\hline & & & 30 & 02 & - \\
\hline & & & 60 & 0,25 & - \\
\hline & & & 30 & 0,5 & - \\
\hline \multirow{5}{*}{6} & \multirow{5}{*}{ Enretobacter spp. } & \multirow{5}{*}{$2 \times 10^{9}$} & 30 & \multirow{2}{*}{0,1} & - \\
\hline & & & 60 & & - \\
\hline & & & 30 & \multirow{2}{*}{0,25} & - \\
\hline & & & 60 & & - \\
\hline & & & 30 & 0,5 & - \\
\hline
\end{tabular}

Примітка: "+" - наявність росту, "-" - відсутність росту

Аналізуючи отримані результати в таблиці 3 можна вказати, що засіб дезінффікуючий «Контавір» у концентрації $0,1 \%$ проявляє бактерицидну активність стосовно $S$. aureus 209-P, Salmonela Cholerasuis, Streptococcus faecium, Clostridium perfringens, Klebsiella spp., при експозиції 60 хвилин,а із Enretobacter spp. при 30 хвилинах контактування. Антимікробні властивості дезінфектант проявляє в концентрації 0,25 та 0,5 \% стосовно S. aureus 209-P, Salmonela Cholerasuis, Streptococcus faecium, Clostridium perfringens, Klebsiella spp., Enretobacter spp. при ексозиції 30 хвилин.

Дослідження віруліцидної дії засобу «Контавір» суспензійним методом. Проводили визначення віруліцидної активності дезінфектанту «Контавір» відносно ДНК- містких вірусів: хвороба Ауєскі; Трансмісивний гастроентерит; парагрип великої рогатої худоби; вірусна діарея великої рогатої худоби та РНК- містких вірусів: збудник хвороби Ньюкасла; Гамборо; Марека; хвороба Тешена.

Про вірусну активність дезінфектанту судили по ная- вності або відсутності цитопатогенної дії, що викликається вірусом, або по іншим проявам, які вказують на репродукцію вipycy.

Результати віруліцидної дії дезінфектанту «Контавір» наведені в таблицях 4-5.

Аналіз отриманих результатів вказує на те, що дезінфрікуючий засіб «Контавір» у концентрації 0,25 \% при експозиції 30 хвилин проявляє віруліцидну дію стосовно збуднику трансмісивного гастроентериту свиней. Віруліцидні властивості дезінфектант проявляє при експозиції 60 хвилин в концентрації 0,25 \% до збудників хвороби Ауєскі; парагрипу-3 великої рогатої худоби та вірусної діареї великої рогатої худоби.

Також проводили дослідження віруліцидних властивостей дезінфектанту «Контавір» відносно РНК- містких вірусів: збудник хвороби Ньюкасла; Гамборо; Марека; хвороба Тешена. 
Таблиця 4

Визначення віруліцідної активності дезінфектанту «Контавір» відносно ДНК- містких вірусів

\begin{tabular}{|c|c|c|c|c|c|c|}
\hline $\begin{array}{l}\text { № } \\
\text { 3/ח }\end{array}$ & $\begin{array}{l}\text { Збудник вірусного } \\
\text { захворювання }\end{array}$ & $\begin{array}{c}\text { Tитр } \\
\text { вірусвмісної } \\
\text { рідини в } 1 \text { cм³ }^{3}\end{array}$ & $\begin{array}{c}\text { Біологічна } \\
\text { модель під час } \\
\text { дослідження }\end{array}$ & $\begin{array}{l}\text { Тривалість } \\
\text { експозиції, } \\
\text { хв. }\end{array}$ & $\begin{array}{l}\text { Концентрація, } \\
\text { «Контавір»\% }\end{array}$ & Результати дослідження \\
\hline \multirow{4}{*}{1} & \multirow{4}{*}{ хвороба Ауєскі } & \multirow{4}{*}{$10^{7} \lg$} & \multirow{4}{*}{$\begin{array}{l}\text { культура } \\
\text { клітин РК-15 }\end{array}$} & 30 & \multirow{2}{*}{0,25} & Має слабкий віруліцидний ефект \\
\hline & & & & 60 & & Має віруліцидний ефект \\
\hline & & & & 30 & 0,5 & Має віруліцидний ефект \\
\hline & & & & 30 & 1,0 & Має віруліцидний ефект \\
\hline \multirow{3}{*}{2} & \multirow{3}{*}{$\begin{array}{l}\text { трансмісивний } \\
\text { гастроентерит }\end{array}$} & \multirow{3}{*}{$10^{6} \lg$} & \multirow{3}{*}{$\begin{array}{l}\text { первинна } \\
\text { культура } \\
\text { клітин нирки } \\
\text { свині }\end{array}$} & 30 & 0,25 & Має віруліцидний ефект \\
\hline & & & & 30 & 0,5 & Має віруліцидний ефект \\
\hline & & & & 30 & 1,0 & Має віруліцидний ефрект \\
\hline \multirow{4}{*}{3} & \multirow{4}{*}{$\begin{array}{l}\text { парагрип-3 великої } \\
\text { рогатої худоби }\end{array}$} & \multirow{4}{*}{$10^{4} \lg$} & \multirow{4}{*}{$\begin{array}{l}\text { культура } \\
\text { клітин Vero }\end{array}$} & 30 & \multirow{2}{*}{0,25} & Має слабкий віруліцидний ефект \\
\hline & & & & 60 & & Має віруліцидний ефект \\
\hline & & & & 30 & 0,5 & Має віруліцидний ефект \\
\hline & & & & 30 & 1,0 & Має віруліцидний ефект \\
\hline \multirow{5}{*}{4} & \multirow{5}{*}{$\begin{array}{l}\text { вірусна діарея } \\
\text { великої рогатої } \\
\text { худоби }\end{array}$} & \multirow{5}{*}{$10^{5} \lg$} & \multirow{5}{*}{$\begin{array}{l}\text { культура } \\
\text { клітин MDBK }\end{array}$} & 30 & \multirow{2}{*}{0,25} & Не має віруліцидного ефекту \\
\hline & & & & 60 & & Має слабкий віруліцидний ефект \\
\hline & & & & 30 & \multirow{2}{*}{0,5} & Має слабкий віруліцидний ефект \\
\hline & & & & 60 & & Має віруліцидний ефект \\
\hline & & & & 30 & 1,0 & Має віруліцидний ефрект \\
\hline
\end{tabular}

Визначення віруліцідної активності дезінфектанту «Контавір» відносно РНК- містких вірусів

\begin{tabular}{|c|c|c|c|c|c|c|}
\hline $\begin{array}{l}\text { № } \\
\text { 3/п }\end{array}$ & $\begin{array}{c}\text { Збудник } \\
\text { вірусного } \\
\text { захворювання }\end{array}$ & $\begin{array}{c}\text { Титр } \\
\text { вірусвмісної } \\
\text { рідини в } 1 \mathrm{~cm}^{3}\end{array}$ & $\begin{array}{c}\text { Біологічна модель під час } \\
\text { дослідження }\end{array}$ & $\begin{array}{c}\text { Тривалість } \\
\text { експозиції, } \\
\text { хв. }\end{array}$ & $\begin{array}{l}\text { Концентрація, } \\
\text { «Контавір»\% }\end{array}$ & Результати дослідження \\
\hline \multirow{4}{*}{1} & \multirow{4}{*}{$\begin{array}{l}\text { Хвороба } \\
\text { Тешена }\end{array}$} & \multirow{4}{*}{$10^{6} \mathrm{lg}$} & \multirow{4}{*}{ культура клітин РК-15 } & 30 & \multirow{2}{*}{0,25} & Має слабкий віруліцидний ефект \\
\hline & & & & 60 & & Має віруліцидний ефект \\
\hline & & & & 30 & 0,5 & Має віруліцидний ефект \\
\hline & & & & 30 & 1,0 & Має віруліцидний есект \\
\hline \multirow{4}{*}{2} & \multirow{4}{*}{$\begin{array}{l}\text { Хвороба } \\
\text { Ньюкасла }\end{array}$} & \multirow{4}{*}{$10^{9} \mathrm{lg}$} & \multirow{4}{*}{ SPF культура клітин } & 30 & \multirow{2}{*}{0,25} & Не має віруліцидного ефекту \\
\hline & & & & 60 & & Має слабкий віруліцидний ефрект \\
\hline & & & & 30 & 0,5 & Має віруліцидний ефект \\
\hline & & & & 30 & 1,0 & Має віруліцидний ефект \\
\hline \multirow{4}{*}{3} & \multirow{4}{*}{$\begin{array}{l}\text { Хвороба } \\
\text { Гамборо }\end{array}$} & \multirow{4}{*}{$10^{5} \mathrm{lg}$} & \multirow{4}{*}{ SPF культура клітин } & 30 & \multirow{2}{*}{0,25} & Не має віруліцидного ефекту \\
\hline & & & & 60 & & Має віруліцидний ефект \\
\hline & & & & 30 & 0,5 & Має віруліцидний ефект \\
\hline & & & & 30 & 1,0 & Має віруліцидний ефект \\
\hline \multirow{4}{*}{4} & \multirow{4}{*}{$\begin{array}{l}\text { Хвороба } \\
\text { Марека }\end{array}$} & \multirow{4}{*}{$10^{5} \lg$} & \multirow{4}{*}{$\begin{array}{l}\text { Первинна культура клітин } \\
\text { фібробластів куриних } \\
\text { ембріонів }\end{array}$} & 30 & \multirow{2}{*}{0,25} & Не має віруліцидного ефекту \\
\hline & & & & 60 & & Має слабкий віруліцидний ефект \\
\hline & & & & 30 & 0,5 & Має віруліцидний ефект \\
\hline & & & & 30 & 1,0 & Має віруліцидний есект \\
\hline
\end{tabular}

За результатами проведених досліджень встановлено, що дезінфікуючий засіб «Контавір» у концентрації 0,25 \% при експозиції 60 хвилин проявляє віруліцидну дію стосовно збуднику хвороби Тешена. Дезінфектант проявляє інактивуючу активність при експозиції 30 хвилин в концентрації 0,5% відносно хвороби Ньюкасла; хвороби Гамборо та хвороби Марека.

\section{Обговорення.}

У разі спалаху інфекційних хвороб тварин необхідно правильно вибрати тип дезінфікуючого засобу і заходи, які використовуються при очищенні заражених ферм. Для повсякденного використання в програмах біобезпеки на рівні ферми виробники повинні враховувати основні ризики, враховувати тип поверхні для дезінфекції і умови, в яких буде використовуватися дезінфікуючий засіб. Також важливою $є$ інфоормація про активність дезінфектанту при наявності органічних залишків, необхідний час контакту, про те, які мікроби надійно знищуються (Szott \& Friese, 2021).

В даній роботі був протестований у лабораторних умовах дезінфікуючий засіб «Контавір» з різними штамами мікроорганізмів (Tishyn et al., 2016). За результатами експериментів встановлено, що засіб дезінфікуючий «Контавір» у концентрації 0,1\% проявляє бактерицидну активність стосовно S. aureus 209-P, Salmonela Cholerasuis, Streptococcus faecium, Clostridium perfringens, Klebsiella spp., при експозиції 60 хвилин, а із Enretobacter spp. при 30 хвилинах контактування. Антимікробні властивості дезінфектант проявляє в концентрації 0,25 та 0,5 \% стосовно S. aureus 209-P, Salmonela Cholerasuis, Streptococcus faecium, Clostridium perfringens, Klebsiella spp., Enretobacter spp. при ексозиції 30 хвилин. Бактерицидна дія засобу «Контавір» сильніша за бактерицидну дію карболової кислоти в 131,5 рази. В присутності високомолекулярного білка бактерицидна дія засобу «Контавір» знижується в 1,61 рази.

При визначенні бактерицидної ефективності дезінфектанту (Shkromada et al., 2019) на різних поверхнях (бетон, пластик, кахель та метал) було встановлено, що дезінфектант «Контавір» проявляє бактерицидні властивості через 10 хвилин експозиції у концентрації 0,25 \% на поверхні металу, пластику та кахелю. На неоднорідній поверхні 
бетону дезінфектант знищує колонії E. coli через 60 хвилин експозиції.

Дослідження віруліцидної дії засобу «Контавір» суспензійним методом проводили відносно ДНК- та РНКмістких вірусів. Встановлено, що «Контавір» у концентрації 0,25\% при експозиції 30 хвилин проявляє віруліцидну дію стосовно більшості ДНК-містких вірусів, В концентрації 0,5 \% засіб «Контавір» діє відносно РНК-містких вірусів (Tishyn et al., 2016).

За результатам проведеного експерименту можна зробити висновок, що для профілактичної та вимушеної дезінфекції при бактеріальних інфекціях сільськогосподарських тварин рекомендується використовувати 0,25 -0,5\% розчин дезінфектанту «Контавір» з розрахунку 0,15-0,25 л робочого розчину на $1 \mathrm{~m}^{2}$ площі при експозиції 30 хвилин.

Перспектива подальшого дослідження: проведення дезінффікуючої активності засобу «Контавір» у виробничих умовах.

\section{Висновки:}

1. За результатами експериментів встановлено, що засіб дезінффікуючий «Контавір» у концентрації 0,1 \% проявляє бактерицидну активність стосовно S. aureus 209-P,
Salmonela Cholerasuis, Streptococcus faecium, Clostridium perfringens, Klebsiella spp., при експозиції 60 хвилин, а із Enretobacter spp. при 30 хвилинах контактування. Антимікробні властивості дезінфектант проявляє в концентрації 0,25 та 0,5 \% стосовно S. aureus 209-P, Salmonela Cholerasuis, Streptococcus faecium, Clostridium perfringens, Klebsiella spp., Enretobacter spp. при ексозиції 30 хвилин.

2. Бактерицидна дія засобу «Контавір» сильніша за бактерицидну дію карболової кислоти в 131,5 рази. В присутності високомолекулярного білка бактерицидна дія засобу «Контавір» знижується в 1,61 рази.

3. Встановлено, що дезінфектант «Контавір» проявляє бактерицидні властивості через 10 хвилин експозиції у концентрації 0,25 \% на поверхні металу, пластику та кахелю. На неоднорідній поверхні бетону дезінфектант знищує колонії Е. coli через 60 хвилин експозиції.

4. За результатами проведених досліджень вичвлено, що дезінфрікуючий засіб «Контавір» у концентрації 0,25 \% при експозиції 60 хвилин проявляє віруліцидну дію стосовно збуднику хвороби Тешената; при експозиції 30 хвилин в концентрації 0,5 \% відносно хвороби Ньюкасла; хвороби Гамборо та хвороби Марека.

\section{References}

1. Tenzin, S., Ogunniyi, A. D., Khazandi, M., Ferro, S., Bartsch, J., Crabb, S., Abraham, S., Deo, P., \& Trott, D. J. (2019). Decontamination of aerosolised bacteria from a pig farm environment using a pH neutral electrochemically activated solution (Ecas4 anolyte). PloS one, 14(9), e0222765. https://doi.org/10.1371/journal.pone.0222765

2. Fablet, C., Dorenlor, V., Eono, F., Eveno, E., Jolly, J. P., Portier, F., Bidan, F., Madec, F., \& Rose, N. (2012). Noninfectious factors associated with pneumonia and pleuritis in slaughtered pigs from 143 farrow-to-finish pig farms. Preventive veterinary medicine, 104(3-4), 271-280. https://doi.org/10.1016/i.prevetmed.2011.11.012

3. Chang, B., Nerandzic, M. M., Kundrapu, S., Sunkesula, V. C., Deshpande, A., \& Donskey, C. J. (2013). Efficacy of dilute hypochlorite solutions and an electrochemically activated saline solution containing hypochlorous acid for disinfection of methicillin-resistant Staphylococcus aureus in a pig skin model. Infection control and hospital epidemiology, 34(11), 1231-1233. https://doi.org/10.1086/673448

4. Shkromada, O., \& Nedzheria, T. (2020). Intensity of infection and means of giardiasis prevention at the farms of ukraine . Technology Transfer: Innovative Solutions in Medicine, 47-50. https://doi.org/10.21303/2585-663.2020.001448

5. Ogunniyi, A. D., Dandie, C. E., Ferro, S., Hall, B., Drigo, B., Brunetti, G., Venter, H., Myers, B., Deo, P., Donner, E., \& Lombi, E. (2019). Comparative antibacterial activities of neutral electrolyzed oxidizing water and other chlorine-based sanitizers. Scientific reports, 9(1), 19955. https://doi.org/10.1038/s41598-019-56248-7

6. Díaz, P., Varcasia, A., Pipia, A. P., Tamponi, C., Sanna, G., Prieto, A., Ruiu, A., Spissu, P., Díez-Baños, P., Morrondo, P., \& Scala, A. (2018). Molecular characterisation and risk factor analysis of Cryptosporidium spp. in calves from Italy. Parasitology research, 117(10), 3081-3090. https://doi.org/10.1007/s00436-018-6000-x

7. Chen, Z., Wang, H., Ionita, C., Luo, F., \& Jiang, X. (2015). Effects of chicken litter storage time and ammonia content on thermal resistance of desiccation-adapted Salmonella spp. Appl Environ Microbiol, 81, 6883-6889. https://doi.org/10.1128/AEM.01876-15

8. Shkromada, O., Palii, A., Palii, A., Skliar, O., Dudchenko, Y., \& Necherya, T. (2019). Improvement of milk quality for micro-climate formation on cattle farms. Bulletin of Sumy National Agrarian University. The Series: Veterinary Medicine, (4 (47), $43-$ 49. https://doi.org/10.32845/bsnau.vet.2019.4.7

9. Dennler-Church, T. E., Butz, J. C., McKinley, J. E., Keim, E. K., Hall, M. C., Meschke, J. S., Mulligan, J. M., Williams, J. F., \& Robins, L. I. (2020). Modification of Major Contributors Responsible for Latrine Malodor on Exposure to Hypochlorous Acid: The Potential for Simultaneously Impacting Odor and Infection Hazards to Encourage Latrine Use. The American journal of tropical medicine and hygiene, 103(6), 2584-2590. https://doi.org/10.4269/ajtmh.20-0553

10. Wohlgemuth, F., Gomes, R. L., Singleton, I., Rawson, F. J., \& Avery, S. V. (2020). Top-Down Characterization of an Antimicrobial Sanitizer, Leading From Quenchers of Efficacy to Mode of Action. Frontiers in microbiology, 11, 575157. https://doi.org/10.3389/fmicb.2020.575157

11. Golovko A. \& Ushkalov V. (2004), Epidemiological monitoring. Escherichia colitis (colibacteriosis) of animals [Epizootolohichnyi monitorynh Esherykhiozu (kolibakteriozu) tvaryn], Veterinary Medicine of Ukraine, No. 2, pp. 6-9.

12. Methodical recommendations (2007) Determination of bactericidal properties of disinfectants, disinfection and control of its quality in tuberculosis of farm animals / zatv. sci. method. Council of the State committee vet honey. Ukraine, December 20.

13. Szott, V., \& Friese, A. (2021). Emission Sources of Campylobacter from Agricultural Farms, Impact on Environmental Contamination and Intervention Strategies. Current topics in microbiology and immunology, 431, 103-125. 
https://doi.org/10.1007/978-3-030-65481-8 5

14. Tishyn, O., Khomyak, R., Kopijchuk, G., Ponomariova, S., \& Danko, M. (2016). Disinfectants with virucidal activity, including african swine fever on the market of Ukraine. Scientific Messenger of LNU of Veterinary Medicine and Biotechnologies. 18, 4(72), 78-85. Retrieved from https://nvlvet.com.ua/ index.php/journal/article/view/989

15. Shkromada, O., Dudchenko, Y., Necherya, T., \& Abubakari Kavla, I. (2019). The research of disinfective properties of kontravir for disinfection of veterinary objects. Bulletin of Sumy National Agrarian University. The Series: Veterinary Medicine, (3 (46), 29-34. https://doi.org/10.32845/bsnau.vet.2019.3.4

16. Tishyn, O.L., Velychko V.O., \& Khom"yak, R.V. (2016). Dezinfikuyuchi zasoby virulitsydnoyi diyi na rynku Ukrayiny. Naukovo-tekhnichnyy byuleten' Derzhavnoho naukovo-doslidnoho kontrol'noho instytutu veterynarnykh preparativ ta kormovykh dobavok i instytutu biolohiyi tvaryn. 17(2), 356-364.

Tetiana Nedzheria, PhD Student, Sumy National Agrarian University (Sumy, Ukraine)

Preclinical studies of disinfective properties of "Kontavir»

One of the unsolved problems for sanitation and hygiene in veterinary medicine is the emergence of resistance in microorganisms to certain groups of disinfectants that are constantly used. Therefore, there is a need to create new comprehensive disinfectants. The aim of the work was to conduct preclinical studies of the disinfectant properties of "Kontavir». The research was conducted in the educational and scientific laboratory «Veterinary Pharmacy» of Sumy National Agrarian University.

Bactericidal dilution and phenolic coefficient of "Kontavir» disinfectant were determined. The experiment began with the preparation of a solution of "Kontavir» disinfectant and cultures of microorganisms $E$. coli and $S$. aureus. It was found that the bactericidal action of "Kontavir» is 131,5 times stronger than the bactericidal action of Carbolic Acid. In the presence of high molecular weight protein bactericidal action of «Kontavir» is reduced by 1,61 times.

The effectiveness of "Kontavir» disinfectant was determined on test objects: concrete, plastic, tile and metal. Determination of the quality of the disinfection was performed after 10, 40 and 60 minutes. It has been proven that the "Kontavir» disinfectant exhibits bactericidal properties after 10 minutes of exposure at a concentration of $0,25 \%$ on the surface of metal, plastic and tile. On an inhomogeneous concrete surface, the disinfectant destroys E. coli colonies after 60 minutes of exposure.

The bactericidal activity of «Kontavir» disinfectant was also studied by the suspension method against enterobacteria, grampositive cocci, gram-negative rods and bacilli. The $0,1 \%$ concentration of "Kontavir» disinfectant exhibits bactericidal activity against S. aureus 209-P, Salmonela Cholerasuis, Streptococcus faecium, Clostridium perfringens, Klebsiella spp. at 60 minutes of exposure, and as regarding Enretobacter spp. at 30 minutes of exposure. In concentrations of 0,25 and 0,5\% the disinfectant exhibits antimicrobial properties against S. aureus 209-P, Salmonela Cholerasuis, Streptococcus faecium, Clostridium perfringens, Klebsiella spp., Enretobacter spp. at 30 minutes of exposure.

Studies of the virucidal action of "Kontavir» by suspension method were performed against DNA and RNA-containing viruses. It was found that a $0,25 \%$ concentration of "Kontavir» at 30 minutes exposure has a virucidal effect on the causative agent of transmissible gastroenteritis of pigs; at 60 minutes exposure has a virucidal effect on Aujeszky's disease; parainfluenza-3 cattle and viral diarrhea of cattle. A 0,25\% concentration of "Kontavir» at 60 minutes exposure has a virucidal effect on the pathogen of Teshen's disease; a 0,5\% concentration at an exposure of 30 minutes has a virucidal effect on the pathogens of Newcastle's, Gamboro's and Marek's diseases.

Key words: Phenol coefficient, Protein index, bactericidal activity, test objects, virucidal activity.

Дата надходження до редакції: 20.11.2020 p. 